\title{
MOTIVASI BELAJAR MAHASISWA KEPERAWATAN KRITIS MENGGUNAKAN METODE PEMBELAJARAN KOOPERATIF TIPE THINK-PAIR-SQUARE (TPS)
}

\section{STUDENT MOTIVATION TO LEARN CRITICAL NURSING USING THINK-PAIR-SQUARE (TPS) TYPE OF COOPERATIVE LEARNING}

\author{
I Nyoman Asdiwinata ${ }^{1}$, AA Istri Dalem Hana Yundari ${ }^{2}$, Ni Luh Gede Intan Saraswati ${ }^{3}$ \\ STIKes Wira Medika Bali
}

\begin{abstract}
ABSTRAK
Latar belakang: Aktivitas belajar yang dilakukan oleh mahasiswa selama ini hanya lebih mengandalkan mata kuliah yang sifatnya ceramah. Hal tersebut dirasakan kurang memberikan tantangan dan semangat dalam melakukan proses pembelajaran. Hal ini terbukti dari menurunnya minat mahasiswa untuk hadir dalam setiap perkulihaan yang dilaksanakan. Tentunya motivasi dalam belajar akan sangat dipengaruhi oleh banyak faktor, internal ataupun eksternal. Penerapan model pembelajaran tertentu diharapkan mampu membantu mahasiswa untuk mencapai target pembelajaran. Diharapkan model pembelajaran kooperatif tipe thinik-pair-square mampu meningkatkan motivasi belajar mahasiswa. Tujuan: Tujuan dari penelitian ini adalah untuk mengeksplorasi efektivitas model pembelajaran kooperatif tipe think-pair-square (TPS) terhadap motivasi belajar keperawatan kritis. Metode: Penelitian ini menggunakan design penelitian dengan teknik one group pretest-posttest. pengumpulan data menggunakan purposive sampling. Kuesioner telah diuji menggunakan Model Rasch untuk melihat reliabilitas dan validitas dan hasil logit adalah 0,89. Hasil: Hasil penelitian ini menunjukkan bahwa mayoritas responden adalah perempuan yaitu sebanyak $85 \%$. Berdasarkan hasil uji beda menggunakan uji Wilcoxon Signed Rank Test pada kelompok perlakukan didapatkan nilai signifikansi kurang dari 0,05 yang membuktikan terdapat perbedaan motivasi sebelum dan sesudah diberikan perlakuan. Kesimpulan: Perubahan nilai motivasi pada mahasiswa setelah diberikan tipe pembelajaran think-pair-square yang berbeda dari sebelumnya menunjukkan bahwa metode ini berhasil bagi mahasiswa dalam melakukan pembelajaran keperawatan kritis
\end{abstract}

Kata kunci: Think Pair Square, Motivasi Belajar, Keperawatan Kritis

\begin{abstract}
Background: The learning activities carried out by students so far only rely more on lecture subjects. This is felt to be less challenging and enthusiastic in carrying out the learning process. This is evident from the decline in student interest in attending every lecture that is carried out. Of course, motivation in learning will be greatly influenced by
\end{abstract}


Bali Medika Jurnal.

Vol 8 No 1, 2021: 64-71

DOI: https://doi.org/10.36376/bmj.v8i1

many factors, internal or external. The application of certain learning models is expected to be able to help students achieve learning targets. It is expected that the thinik-pair-square type of cooperative learning model can increase student learning motivation. Purpose: The purpose of this study was to explore the effectiveness of the think-pair-square (TPS) cooperative learning model on critical nursing learning motivation. Methods: This study used a research design with one group pretest-posttest technique. data collection using purposive sampling. The questionnaire was tested using the Rasch Model to see its reliability and validity and the logit result was 0.89 . Results: The results of this study indicate that the majority of respondents are women as much as $85 \%$. Based on the results of different tests using the Wilcoxon Signed Rank Test in the treatment group, the significance value was less than 0.05 which proved that there were differences in motivation before and after being given treatment. Conclusion: Changes in the motivation value of students after being given a different type of think-pair-square learning indicate that this method was successful for students in conducting critical nursing learning. Keywords: Think Pair Square, Learning Motivation, Critical Care Nursing

\begin{tabular}{ll}
\hline Alamat Korespondensi & : STIKes Wira Medika Bali \\
Email & : asdiwinata@gmail.com \\
\hline
\end{tabular}

\section{PENDAHULUAN}

Asosiasi Institusi Pendidikan Ners Indonesia (AIPNI) telah menyusun kurikulum berbasis kompetensi yang mengacu pada Kerangka Kualifikasi Nasional Indonesia (KKNI) untuk membentuk lulusan tenaga keperawatan yang professional (AIPNI, 2016). Selama proses akademik mahasiswa harus menempuh beberapa aspek keilmuan didalamnya. Salah satu aspek keilmuan yang harus dipelajari mahasiswa keperawatan untuk membentuk dirinya menjadi seorang perawat professional adalah keperawatan kritis.

Keperawatan kritis menitikberatkan pada kemampuan pengkajian, menganalisa dan pengambilan keputusan yang tepat pada kondisi klien yang terancam nyawanya (Emergency Nurse Association, 2014). Mempelajari keperawatan kritis memerlukan dasar yang kuat seperti keilmuan medikal bedah yang telah diperoleh pada awal semester, sehingga dengan dasar yang kuat mahasiswa mampu melakukan klarifikasi keilmuan yang mereka miliki guna mendapatkan pengetahuan yang cukup. Mata kuliah keperawatan kritis merupakan salah satu mata kuliah yang cukup menantang, karena didalamnya tidak hanya berfokus pada perkuliahan dengan metode ceramah saja, namun juga terdapat penugasan serta praktikum yang mengharuskan mahasiswa untuk mampu berkolaborasi dan sharing keilmuan yang mereka miliki.

Tantangan dan beban mata kuliah yang cukup banyak tidak jarang berdampak pada menurunnya motivasi belajar mahasiswa. Hal ini terlihat pada tingkat presensi yang menurun sampai $45 \%$ dan tidak tampaknya peningkatan dari nilai mata kuliah keperawatan kritis pada mahasiswa dari STIKes Wira Medika Bali pada tahun akademik 2018/2019 (Laporan Akademik Prodi, 2019). Dengan menggunakan model pembelajaran berupa ceramah, diskusi kelompok kecil, dan belajar mandiri. Aktivitas belajar yang dilakukan oleh mahasiswa selama ini hanya lebih mengandalkan mata kuliah yang sifatnya ceramah. 
Mahasiswa cenderung pasif dalam mengemukakan pendapat, ide, ataupun melakukan analisa didalam diskusi kelompok kecil. Sehingga, diperlukan upaya yang berbeda untuk tetap membuat mahasiswa mampu tetap tertarik dan semangat dalam mengikuti setiap proses pembelajaran (Hamalik, 2011).

Proses pembelajaran yang dilakukan oleh mahasiswa agar masih tetap memberikan dampak positif banyak dipengaruhi oleh faktor-faktor, baik itu secara internal maupun eksternal (Slameto, 2013). Salah satu hal yang dapat terlihat dan terukur adalah motivasi belajar mahasiswa dalam mengikuti proses pembelajaran. Proses pembelajaran yang baik tidak hanya didasarkan pada model pembelajaran yang baik, tetapi ada faktor lain yang juga mampu memberikan dampak terhadap keseluruhan proses pembelajaran yaitu adanya kemauan yang genuine dari mahasiswa untuk belajar dan memperoleh pelajaran. Kemauan tersebut dapat terlihat dari motivasi belajar mahasiswa.

Penerapan model pembelajaran tertentu diharapkan mampu membantu mahasiswa untuk mencapai target pembelajaran. Salah satunya adalah model pembelajaran kooperatif (Suprijono, 2013). Model pembelajaraan kooperatif yang diharapkan adalah tipe Think-Pair-Square. Dalam perencanaannya, penggunaan model pembelajaran ini akan menekankan mahasiswa untuk secara maksimal menggunakan kemampuan analisa (think), memberikan kesempatan mahasiswa untuk berbagi pendapat (pair) dan mengajarkan mahasiswa untuk menghargai pendapat orang lain dalam diskusi besar (square) (Millis \& Cottell, 2008; Sudjana, 2014). Tahapan ini diharapkan mampu meningkatkan aktivitas belajar dan keterampilan menganalisa yang akan berdampak pada perubahan kompetensi yang dimiliki terkait dengan keperawatan kritis.

Keberhasilan suatu proses pembelajaran diukur dari hasil capaian sesuai dengan standar kompetensi yang ditetapkan. Pengukuran keterampilan kompetensi dasar akan memberikan penilaian mahasiswa tersebut kompeten atau tidak. Hasil ini menjadi bahan evaluasi pelaksanaan proses pembelajaran khususnya saat praktik profesi dan perkuliahan Keperawatan Kritis. Penelitian ini bertujuan untuk mengeksplorasi motivasi belajar mahasiswa yang menempuh pembejalaran keperawatan kritis menggunakan metode pembelajaran kooperatif tipe think-pair-square (TPS)

\section{METODE PENELITIAN}

Penelitian ini merupakan studi kuasi eksperimen dengan menggunakan rancangan pre test-post test with control group design. Pada desain ini terdapat dua kelompok yang dipilih secara acak dengan pemberian model pembelajaran kooperatif tipe think-pair-square untuk kelompok intervensi dan model pembelajaran konvensional yang sudah diterapkan selama ini di STIKes Wira Medika Bali untuk kelompok control (Wood \& Haber, 2014). Seluruh data ordinal yang diperoleh dari kuesioner ditransformasikan ke dalam nilai logit menggunakan RASCH Model. Sampel dalam penelitian ini adalah mahasiswa tingkat enam di STIKes Wira Medika Bali yang diambil menggunakan tehnik purposive sampling yang memenuhi kriteria inklusi. Jumlah sampel pada penelitian ini sebanyak 20 orang. Penelitian ini dilaksanakan pada bulan Feburari-Agustus 2020. 
Bali Medika Jurnal.

Vol 8 No 1, 2021: 64-71

DOI: https://doi.org/10.36376/bmj.v8i1

Sumber data pada penelitian ini adalah mahasiswa semester enam yang sedang mengikuti pembelajaran keperawatan kritis. Tehnik pengumpulan data dilakukan dengan memberikan kuesioner pretest motivasi belajar terlebih dahulu kemudian setelah itu penerapan model pembelajaran TPS dilakukan pada sub mata kuliah yang mengedepankan proses analisis diskusi dan penyampaian pendapat terkait kasus yang relevan dengan keperawatan kritis dan setelah proses perkuliahan selesai akan diberikan post test motivasi belajar.

Kemudian dilakukan persamaan persepsi dengan 2 enumerator yang berasal dari mahasiswa semester IV tentang tujuan, cara pengumpulan data penelitian dan tugas enumerator. Pada saat pengambilan data, peneliti dan enumerator melakukan verifikasi pada mahasiswa yang benar-benar telah memiliki nilai dan dinyatakan lulus. Selanjutnya melakukan pendekatan kepada calon responden dengan menjelaskan tujuan, manfaat dan cara penelitian. Jika calon responden setuju untuk berpartisipasi maka diberikan informed consent. Setelah data terkumpul maka data ditabulasi, dientry dan dilakukan analisis deskriptif dengan menyajikan kedalam tabel distribusi frekuensi.

Analisis data yang digunakan dalam penelitian ini adalah analisis univariat dan bivariat. Analisis univariat dillakukan pada data demografik responden dan analisis bivariat dilakukan pada seluruh responden penelitian menggunakan nilai pretest dan posttest. Uji yang digunakan adalah Wilcoxon Sign Rank Test.

\section{HASIL DAN PEMBAHASAN}

\section{Hasil Penelitian}

Penelitian ini berfokus pada motivasi belajar mahasiswa menggunakan metode pembelajaran kooperatif TPS dalam mata kuliah keperawatan kritis. Berdasarkan data demografi dapat dilihat pada table berikut ini.

$\underline{\text { Tabel 1. Distribusi frekuensi responden berdasarkan jenis kelamin }}$

\begin{tabular}{lll}
\hline Value & Frequency & Percent \\
\hline Laki-laki & 3 & 15 \\
\hline Perempuan & 17 & 85 \\
\hline Total & 20 & \\
\hline
\end{tabular}

Penelitian ini menggunakan data demografi berupa jenis kelamin saja. Dari 20 orang responden yang dijadikan sampel penelitian, jenis kelamin perempuan memiliki persentase lebih banyak dibandingkan laki-laki yaitu sebanyak 85\%.

\section{Hasil Pre test}

Berdasarkan hasil pemberian kuesioner sebelum diberikannya intervensi pada 20 orang sampel penelitian dapat dilihat pada table dibawah ini.

Tabel 2. Hasil pretest

\begin{tabular}{lll}
\hline Value & Frequency & Percent \\
\hline 51.00 & 1 & 5.0 \\
\hline 63.00 & 1 & 5.0 \\
\hline 65.00 & 2 & 10.0 \\
\hline 68.00 & 3 & 15.0 \\
\hline 69.00 & 1 & 5.0 \\
\hline
\end{tabular}


DOI: https://doi.org/10.36376/bmj.v8i1

\begin{tabular}{lll}
\hline 70.00 & 1 & 5.0 \\
\hline 74.00 & 2 & 10.0 \\
\hline 75.00 & 1 & 5.0 \\
\hline 77.00 & 1 & 5.0 \\
\hline 78.00 & 2 & 10.0 \\
\hline 79.00 & 1 & 5.0 \\
\hline 81.00 & 1 & 5.0 \\
\hline 85.00 & 1 & 5.0 \\
\hline Total & 20 & 100 \\
\hline
\end{tabular}

Hasil Posttest

Setelah diberikannya perlakuan yaitu pemberian model pembelajaran kooperatif tipe TPS, selama 14 kali pertemuan kemudian dlakukan pengukuran kembali motivasi belajar mahasiswa yang dapat dilihat pada table dibawah ini.

Tabel 3. Hasil Posttest

\begin{tabular}{lll}
\hline Value & Frequency & Percent \\
\hline 81.00 & 8 & 40 \\
\hline 82.00 & 4 & 20 \\
\hline 83.00 & 3 & 15.0 \\
\hline 84.00 & 2 & 10.0 \\
\hline 87.00 & 1 & 5.0 \\
\hline 92.00 & 1 & 5.0 \\
\hline 94.00 & 1 & 10.0 \\
\hline Total & 20 & 100 \\
\hline
\end{tabular}

\section{Hasil Uji Wilcoxon Sign Rank Test}

Setelah didapatkan hasil pretest dan posttest, maka kedua data tersebut dilakukan uji berpasangan untuk menemukan hasil apakah pemberian model pembelajaran kooperatif tipe TPS memberikan peningkatan motivasi belajar mahasiswa. Berdasarkan hasil uji tersebut dapat dilihat pada table dibawah ini.

Tabel 4. Hasil uji beda

\section{Hypothesis Test Summary}

\begin{tabular}{|c|c|c|c|c|}
\hline & Null Hypothesis & Test & Sig. & Decision \\
\hline 1 & $\begin{array}{l}\text { The median of differences } \\
\text { between NilaiPreEx and } \\
\text { NilaiPostEx equals } 0 \text {. }\end{array}$ & $\begin{array}{l}\text { Related- } \\
\text { Samples } \\
\text { Wilcoxon } \\
\text { Signed Rank } \\
\text { Test }\end{array}$ & .000 & $\begin{array}{l}\text { Reject the } \\
\text { null } \\
\text { hypothesis. }\end{array}$ \\
\hline
\end{tabular}

Asymptotic significances are displayed. The significance level is .05. 
Bali Medika Jurnal.

Vol 8 No 1, 2021: 64-71

ISSN : 2615-7047

DOI: https://doi.org/10.36376/bmj.v8i1

\section{Diskusi Hasil Penelitian}

Motivasi belajar mahasiswa dalam keperawatan kritis memperoleh hasil yang lebih kecil dari 0,05. Hasil tersebut menunjukkan terjadi hubungan bermakna antara sebelum dan sesudah diberikannya perlakuan melalui model pembelajaran kooperatif Think Pair Square (TPS). Selaras dengan teori motivasi yang dikemukakan oleh Uno (2014) bahwa terdapat beberapa faktor yang dapat memengaruhi motivasi belajar mahasiswa yang direduksi menjadi dua faktor yaitu faktor internal dan faktor eksternal. Faktor internal bersumber dari dalam diri mahasiswa seperti kondisi jasmani dan rohani, cita-cita/aspirasi, kemampuan siswa, perhatian dan lain-lain, sedangkan faktor eksternal berasal dari luar diri siswa seperti upaya pengajar selama memberikan materi yang diharapkan mampu merangsang keinginan mahasiswa untuk belajar, fasilitas belajar dan kondisi lingkungan di sekitar mahasiswa (Marini, As'ari, \& Chandra, 2013).

Konsep teori tersebut dapat mengarahkan kita untuk membangun sebuah argumen bahwa penggunaan teknik pembelajaran kooperatif (think pair square) merupakan bagian dari pengaruh faktor eksternal yaitu sebuah upaya pengajar/dosen dalam mengembangkan teknik pengajaran kreatif melalui metode pembelajaran tersebut yang berpengaruh pada motivasi belajar mahasiswa. Hal tersebut didukung oleh penelitian sebelumnya oleh Rondi (2014) yang meneliti tentang motivasi belajar dan prestasi belajar siswa melalui faktor kompetensi guru dan fasilitas belajar, dengan hasil yang menunjukan bahwa terdapat pengaruh positif secara parsial pada kedua faktor tersebut terhadap motivasi belajar.

Sebuah upaya yang dimiliki oleh pengajar dalam hal ini selain merujuk pada keterampilan pengajar/dosen dalam mengajar atau menyampaikan materi juga dilihat dari bagaimana kretaifitas mereka dalam memilih dan menerapkan metode pengajaran yang tentu saja disesuaikan dengan karakteristik mata kuliah yang akan diajarkan (Hasana, 2010). Penelitian ini berfokus pada mata kuliah keperawatan kritis yang memiliki karakteristik dengan menitikberatkan pada kemampuan melakukan pengkajian, menganalisa dan pengambilan keputusan yang tepat dan cepat pada kondisi klien yang mengancam nyawa. Metode pengajaran yang sudah diterapkan sebelumnya pada pembelajaran keperawatan kritis adalah metode tutorial atau ceramah namun berdasarkan hasil uji rata-rata sebelum diberikan intervensi sebagian besar berada pada nilai 65 sebesar $15 \%$ dan terlihat mengalami peningkatan pada hasil uji rata-rata gambaran pada saat setelah diberikan pengajaran dengan model pembelajaran TPS yaitu sebagian besar berada pada nilai 81 sebesar $40 \%$. Hal ini sejalan dengan penelitian oleh Januartini (2016) yang memaparkan terjadinya pengaruh yang signifikan penggunaan model pembelajaran koperatif TPS terhadap hasil belajar dan dijelaskan bahwa peserta didik yang belajar dengan menggunakan model Think Pair Square dan model pembelajaran ini secara signifikan memperoleh hasil belajar yang lebih baik, motivasi belajar yang sangat tinggi dan respon siswa yang positif jika nanti diukur pada mahasiswa yang menggunakan model pembelajaran konvensional.

Perbedaan motivasi pada hasil penelitian ini juga dapat dikaitkan dengan faktor perbedaan jenis kelamin antara laki-laki dan perempuan dengan perbandingan yang cukup signifikan, meskipun hal tersebut tidak sepenuhnya mampu merepresentasi secara keseluruhan (Saragi, 2015). Karakteristik jenis kelamin mahasiswa berdasarkan pada penelitian ini menunjukkan hasil 
sebagian besar responden berjenis kelamin perempuan dengan presentase sebesar 85\%. Pada penelitian sebelumnya oleh Asmita (2017) menyebutkan bahwa perempuan lebih aktif dan berprestasi serta memiliki motivasi belajar yang lebih tinggi dibandingkan laki-laki. Sejalan dengan konsep teori yang memaparkan tentang indikator motivasi belajar dan teori genetika wanita yang didominasi kromosom $\mathrm{X}$, maka akan ditemukan bahwa kognitif perempuan itu lebih tinggi dibandingkan laki-laki yang memiliki kromosom $\mathrm{Y}$ dalam dirinya, dimana kromosom $\mathrm{X}$ berkaitan dengan pemrosesan kognitif tingkat tinggi. Hal tersebut diartikan bahwa wanita memiliki dua kali pemrosesan tingkat tinggi dibandingkan laki-kali sehingga perempuan lebih mampu memaknai indikator motivasi belajar dibandingkan laki-laki.

Pada penelitian ini jumlah antara laki-laki dan perempuan termasuk tidak seimbang dalam jumlah sehingga untuk menyatakan jenis kelamin tertentu memiliki kemampuan yang lebih baik dibandingkan dengan yang lain belum tepat, walaupun dari hasil yang terlihat mahasiswa perempuan memiliki nilai motivasi yang lebih baik dibandingkan dengan laki-laki, namun hal berbeda disampaikan oleh Suosa (2012) dalam penelitiannya yang mengungkapkan bahwa antara lakilaki dan perempuan terdapat beberapa perbedaan dengan hasil uji coba bahwa perempuan lebih baik dalam uji coba kecepatan pemahaman, kelancaran berbicara, menenatukan penempatan subjek (mengurutkan) mengidentifikasi ciri-ciri spesifik subjek, ketepatan tugas-tugas manual.

\section{SIMPULAN DAN SARAN}

Penelitian ini berupaya untuk mengeksplorasi model pembelajaran kooperatif tipe TPS dengan motivasi belajar mahasiswa. Hasil penelitian yang didapatkan bahwa sebagian besar responden berjenis kelamin perempuan. Hasil uji beda didapatkan bahwa terdapat perbedaan signifikan antara nilai pre dan posttest motivasi belajar mahasiswa dalam keperawatan kritis. Secara keseluruhan penelitian ini masih jauh dari kesempurnaan, beberapa variabel perancu yang mungkin saja dapat memengaruhi hasil penilaian belum dapat dikontrol, sehingga diharapkan ada penelitian lanjutan yang mampu menyempurnakan hasil penelitian ini. Penelitian ini diharapkan mampun memberikan alternatif baru bagi pengajar untuk menerapkan sebuah metode pembelajaran yang mampu memberikan motivasi bagi mahasiswa selama mengikut proses pembelajaran.

\section{UCAPAN TERIMAKASIH}

Terimakasih peneliti sampaikan kepada Kementrian Pendidikan dan Kebudayaan Republik Indonesia yang telah mempercayakan dan memberikan dukungan dana, sehingga penelitian ini dapat terlaksana. Kepada Ketua STIKes Wira Medika Bali atas diberikannya ijin penelitian dan senantiasa mendukung terlaksananya penelitian-penelitian yang bersifat akademis guna meningkatkan kualitas dari proses pembelajaran dan seluruh pihak-pihak yang terlibat dalam terlaksananya penelitian ini kami ucapkan terimakasih. 


\section{DAFTAR PUSTAKA}

AIPNI. (2016). Kurikulum Inti Pendidikan Ners 2016. Jakarta: AIPNI.

Asmita, S. H. (2017). Motivasi Belajar Ditinjau Dari Perbedaan Jenis Kelamin Dan Status Mahasiswa Di Fakultas Psikologi UIN Malang. Universitas Islam Negeri Malang.

Emergency Nurse Association. (2014). Scope of Emegency Nurse Practice. USA: Emergency Nurse Association.

Hamalik, O. (2011). Proses Belajar Mengajar. Jakarta: Bumi Aksara.

Hasana, N. (2010). Pengaruh Keterampilan Mengajar Guru dan Fasilitas Belajar terhadap Motivasi Belajar. Universitas Islam Negeri Malang.

Januartini, P. D. (2016). Studi Komparatif Model Pembelajaran Think Pair Square Dan Think Pair Share Terhadap Motivasi Dan Hasil Belajar Siswa Mapel Tik Kelas X SMA N 1 Sukasada. Jurnal Pendidikan Teknologi Dan Kejuruan, $13(2), 148-165$.

Marini, As'ari, A. R., \& Chandra, T. D. (2013). Peningkatan Motivasi Belajar Siswa Melalui Penerapan Pendekatan Realistic Mathematics Education (RME). Jurnal Pendidikan, 2(4).

Millis, B. J., \& Cottell, P. G. (2008). Think Pair Square. Retrieved from weer.wisc.edu website: http://www.weer.wisc.edu/archive/c11/CL/doinggcl/thinksq.htm

Rondi. (2014). Pengaruh Kompetensi Guru dan Fasilitas Belajar terhadap Motivasi Belajar dan Prestasi Belajar Siswa. Universitas Islam Negeri Malang.

Saragi. (2015). Perbedaan Motivasi Belajar Siswa Berjenis Kelamin Perempuan dan Laki-Laki SMK Swasta Bandung. Universitas Muhammadiyah Sumatera.

Slameto. (2013). Belajar dan Faktor-Faktor yang Mempengaruhinya. Jakarta: Bina Aksara.

Sudjana, N. (2014). Dasar-Dasar Proses Belajar Mengajar. Bandung: Sinar Baru Algesindo.

Suosa, D. (2012). Bagaimana Otak Belajar (4th ed.). Jakarta: EGC.

Suprijono, A. (2013). Cooperative Learning. Yogyakarta: Pustaka Pelajar.

Uno, H. B. (2014). Teori motivasi dan Pengukurannya (Analisis di Bidang Pendidikan). Jakarta: Bumi Aksara.

Wood, G. L., \& Haber, J. (2014). Nursing Research; Methods And Critical Appraisal For Evidence-Based Practice (8th ed.). St. Louis: Elsevier Mosby. 